\title{
Marshall's Plan: The Early Supreme Court and Statutory Interpretation
}

\author{
John Choon Yoo
}

\section{INTRODUCTION}

In Wisconsin Public Intervenor v. Mortier, ${ }^{1}$ an innocuous case of the 1990 Term involving bugs, molds, and mice (or rather, how to kill them), two Supreme Court Justices engaged in a sharp debate over the Marshall Court's approach to statutory interpretation. Mortier raised the question of whether the Federal Insecticide, Fungicide, and Rodenticide Act, ${ }^{2}$ which sets labeling and registration standards for pesticides, preempted states and localities from regulating the use of pesticides in their jurisdictions. The Wisconsin Supreme Court held that the Act did preempt local regulation. ${ }^{3}$

Although the Justices unanimously agreed to overrule the Wisconsin Supreme Court, sparks flew when Justices White and Scalia disagreed over whether Congress intended to preempt state law. ${ }^{4}$ Writing for the Court, White delved into the legislative history and found it inconclusive, thus leading him to decide that Congress had not intended to preempt state law. ${ }^{5}$ In his concurrence, Scalia argued that the legislative history did show an intent to preempt state authority, but joined in the majority's decision because he maintained that the Court should cease relying on committee reports. Committee reports were "unreliable," wrote Scalia, "not only as a genuine indicator of congressional intent but as a safe predictor of judicial construction."

That's when they dragged in Chief Justice John Marshall. Defending the majority's reliance upon legislative history, White cited two Marshall opinions to show that "[o]ur precedents demonstrate that the Court's practice of utilizing

1. 111 S. Ct. 2476 (1991).

2. 7 U.S.C. $\S \S 136 a-136 y$ (1988).

3. Mortimer v. Town of Casey, 452 N.W.2d 555 (Wis. 1990).

4. When deciding preemption questions, the Court first decides whether Congress intended to supplant state law. The Court often construes intent by examining the text of the statute and the legislative history, whether state and federal law conflict, whether state law blocks the execution of federal objectives, and the comprehensiveness of the federal scheme. See Florida Lime \& Avocado Growers, Inc. v. Paul, 373 U.S. 132 (1963); Hines v. Davidowitz, 312 U.S. 52 (1941).

5. 111 S. Ct. at 2484.

6. Id. at 2488 (Scalia, J., concurring). 
legislative history reaches well into its past."7 Scalia retorted that the "recent practice of relying upon legislative material to provide an authoritative interpretation of a statutory text" certainly "would have shocked John Marshall." Both Justices were using the Marshall Court in an ongoing debate over whether or not to use legislative history in the interpretation of statutes. ${ }^{9}$ Though unclear as to why, both opinions nevertheless recognized the continuing relevance of the Marshall Court's jurisprudence on statutory interpretation.

This Note examines the practice of statutory interpretation in the early Republic. Because the Constitution does not say how courts should read statutes, and because this question did not arise during the constitutional or ratifying conventions, this Note will focus on the practice of the Marshall Court. It was during Marshall's tenure that a consistent practice of statutory construction first emerged.

Part I of this Note describes the early American approach to statutory interpretation, as found in the ideas held at the time of the ratification and in early federal cases. Part II reviews Marshall Court opinions construing federal statutes and examines the policies underlying those decisions.

\section{EARLY AMERICAN INTERPRETATION}

Early American practices of statutory construction sought to achieve two contradictory goals. ${ }^{10}$ Steeped in the English legal tradition, many of the Framers sought to interpret the laws so as to achieve equitable outcomes. However, they also expressed a distrust of judicial discretion and of the courts'

7. Id. at 2485 n.4.

8. Id. at 2490 .

9. Commentators have noted the rising voices arguing against the use of legislative history in interpreting federal statutes. See William N. Eskridge, The New Textualism, 37 UCLA L. REV. 621 (1990) (analyzing Supreme Court's revitalization of plain meaning rule); Patricia M. Wald, The Sizzling Sleeper: The Use of Legislative History in Construing Statutes in the 1988-89 Term of the United States Supreme Court, 39 AM. U. L. REV. 277, 281 (1990); Nicholas Zeppos, Legislative History and the Interpretation of Statutes: Toward a Fact-Finding Model of Statutory Interpretation, 76 VA. L. REV. 1295 (1990).

10. The limited scholarship on this subject is concerned not with the methodology or rationales the Framers employed in interpreting statutes, but with constitutional interpretation. These scholars argue over whether the Framers wanted their historically demonstrable intentions to bind future interpreters of the Constitution or whether interpreters should read the text in accordance with their contemporary understandings. Both sides agree that the Framers thought the Constitution should be read in the same manner as statutes and other legal documents, leaving open for debate how the Framers interpreted statutes. "Interpretivists" argue that the Framers thought interpreters should use legislative history in interpreting statutes, implying that they would have approved of attempts to ferret out original intent. "Noninterpretivists" reply that the Framers thought the statute itself, and its writers, sufficiently conveyed the intent interpreters should seek. Professors $H$. Jefferson Powell (non-interpretivist) and Raoul Berger (interpretivist) have been the point men in this bitter debate. $\mathrm{H}$. Jefferson Powell, The Original Understanding of Original Intent, 98 HARV. L. REV. 885 (1985) [hereinafter Powell, Original Understanding]; Raoul Berger, "Original Intention" in Historical Perspective, 54 GEO. WASH. L. REV. 296 (1986) [hereinafter Berger, "Original Intention"]; H. Jefferson Powell, The Modern Misunderstanding of Original Intent, 54 U. CHI. L. REV. 1513 (1987) [hereinafter Powell, Modern Misunderstanding] (book review of RAOUL BERGER, FEDERALISM: THE FOUNDERS' DESIGN (1987)); Raoul Berger, The Founders' Views-According to Jefferson Powell, 67 TEX. L. REV. 1033 (1989). 
role in interpreting statutes. The Framers thus found themselves in the curious position of objecting to chancery courts while at the same time clinging tightly to equity law. These divergent beliefs produced different approaches to statutory interpretation: one valued judicial discretion, while the other grasped for the text alone. Confusion reigned over the Supreme Court's statutory jurisprudence until Marshall devised a new methodology that assimilated both approaches.

\section{A. Early American Views on Interpretation}

By the seventeenth and eighteenth centuries, English common law judges had devised canons of interpretation that they considered part of the law itself. ${ }^{11}$ These canons were loosely organized into a collection of rules for construing ambiguities in statutory texts. While their central purpose involved ferreting out the "intent" of the law, the canons also allowed judges to consider the equities of the case before them. ${ }^{12}$

Blackstone's Commentaries constituted the most influential statement of the English common law at that time. Blackstone argued that judges should seek "the will of the legislator" when confronted with vague statutory language. ${ }^{13}$ Judges could find legislative intent by consulting sources such as "the words, the context, the subject matter, the effects and consequence, or the spirit and reason of the law."14 These sources did not include legislative history, but instead embraced only the text of the statute, other laws, and the common law. ${ }^{15}$

The canons of construction ranged from those that advanced substantive policies to those that defined the meaning of specific words. ${ }^{16}$ Distilling the holdings of several different cases, Blackstone listed ten principal canons. Among them were the rules that: remedial statutes are read broadly to further their purpose; penal statutes are construed strictly; statutes against fraud are liberally construed; an interpretation must harmonize all the clauses of a statute; and the last statute passed by the legislature displaces previous acts on the same subject. ${ }^{17}$

11. Powell, Original Understanding, supra note 10, at 894 .

12. See William S. Blatt, The History of Statutory Interpretation: A Study in Form and Substance, 6 CARDOzo L. REV. 799, 800 (1985) (courts have focused on the "equity of a statute" in interpreting laws).

13. 1 WILLIAM BLACKSTONE, COMMENTARIES *59.

14. Id.

15. In the 1769 case of Millar v. Taylor, for example, the King's Bench refused to consider changes Parliament had made to the Copyright Act of 1710 before its passage. "The sense and meaning of an Act of Parliament," the court noted, "must be collected from what it says when passed into a law; and not from the history of changes it underwent in the house where it took rise. That history is not known to the other house, or to the Sovereign." 4 Burr. 2303, 2332, 98 Eng. Rep. 201, 217 (K.B. 1769). For further discussion of Millar, see Hans W. Baade, "Original Intent" in Historical Perspective: Some Critical Glosses, 69 TEX. L. REV. 1001, 1008 (1991).

16. CARLETON K. ALLEN, LAW IN THE MAKING $482-530$ (7th ed. 1964); RUPERT CROSS, STatuTORY INTERPRETATION 9-19 (1987).

17. I BLACKSTONE, supra note 13 , at $* 87-92$. 
According to Blackstone, judges also should weigh equitable considerations in construing statutes, especially where the legislature did not anticipate the case presented. ${ }^{18}$ A review of English jurisprudence shows that English courts could restrict out-of-date laws, exempt specific cases from the reach of general statutes, or interpret statutes so as to avoid unreasonable results. ${ }^{19}$ These equitable powers gave judges broad discretion in the interpretation of statutes. However, Blackstone cautioned that giving too much leeway to equitable interpretation would "set the judicial power above that of the legislature, which would be subversive of all government."20

Intimately familiar with Blackstone and English decisions, the Framers often referred to these common law authorities in their political writings, oral arguments, and judicial decisions. ${ }^{21}$ But the canons of construction-and their emphasis on equitable interpretations - did not win their complete allegiance. Instead, they believed that the broad judicial discretion of the English courts, especially those of chancery, threatened to undermine the rule of law and the will of the people. When Americans issued their Declaration of Independence in 1776, they rebelled not only against British taxation but against the British legal system as well. Republicans believed that the corrupting threat of judicial discretion was especially dangerous when it came to the interpretation of statutes. By using both the canons of interpretation and equitable factors, the republicans believed, the English judges had overridden the wishes of the people and created their own law. ${ }^{22}$ This, they maintained, undermined the

18. "[I]t is necessary, that when the general decrees of the law come to be applied to particular cases, there should be somewhere a power vested of excepting those circumstances, which (had they been foreseen) the legislator himself would have excepted." Id. at *61.

19. See, e.g., College of Physician's (Dr. Bonham's) Case, 123 Eng. Rep. 928 (C.P. 1609) (striking down statute giving London College of Physicians power to sanction uncertified physicians). Dean Guido Calabresi argues that current courts should have powers-identical to those they exercise in the common law-to change statutory law and to update it when anachronistic. See GUIDO CALABRESI, A COMMON LAW FOR THE AGE OF STATUTES (1982).

20. 1 BLACKSTONE, supra note 13 , at $* 91$.

21. For example, in THE FEDERALIST No. 84, at 512 (Alexander Hamilton) (Clinton Rossiter ed., 1961) [hereinafter all citations to THE FEDERALIST are to this edition], Hamilton defends the Constitution's establishment of the writ of habeas corpus by quoting "[t] he observations of the judicious Blackstone." For an example of the citations to Blackstone in oral arguments before the Supreme Court, see Adams v. Woods, 6 U.S. (3 Cranch) 336, 338 (1805). As the historian Gordon Wood has noted, the early Americans held Blackstone in high esteem because he sought to rationalize and order the great body of the English common law. "The great appeal for Americans of Blackstone's Commentaries stemmed not so much from its particular exposition of English law . . . but from its great effort to extract general principles from the English common law and make of it, as James Iredell said, 'a science." GORDON S. WOOD, THE CREATION OF THE AMERICAN REPUBLIC, 1776-1787, at 10 (1969). Before the revolution, American courts were colonial courts bound by English common law and statutory decisions. Even after the revolution, American courts and lawyers often turned to English decisions and treatises such as Blackstone for guidance, as there were few American decisions widely reported and few if any treatises on American law until the early 19th century. For an important study on the transmission of the common law and legal methods from England to America, see WILLIAM E. NELSON, AMERICANZATION OF THE COMMON LAW: THE IMPACT OF LEGAL ChANGE ON MASSACHUSETTS SOCIETY, 1760-1830 (1975).

22. WOOD, supra note 21 , at 304 . If judges, one revolutionary writer argued, "put such a construction on matters as they think most agreeable to the spirit and reason of the law ... they assume what is in fact the prerogative of the legislature." Id. at 302. One Anti-Federalist writer argued: "It is well known, that the 
rule of law and threatened democracy. "Relieve the judges from the rigour of text law, and permit them, with pretorian discretion, to wander into its equity, and the whole legal system becomes incertain," Thomas Jefferson wrote in $1785 .^{23}$

To cabin judicial discretion, some of the Framers believed that courts should consult only a statute's text. If courts had to read statutes narrowly, they would no longer have the discretion to fashion unauthorized laws. This would restrain the judiciary, which otherwise "would be a monster whose existence should not be suffered one moment in a free country wherein every power is dangerous which is not bound up by general rules."24 This theme in revolutionary thought expressly rejected Blackstone's idea that judges could weigh the equities of a statute. Judges "must take the law as it is, and by all due and proper means execute it, without any pretense to judge of its right or wrong."25

Even though they dreaded judicial discretion, however, Americans cherished the equity in English and American law. Partially, this ambiguity of American law arose from the provincial character of law in the colonies. Colonial common law sometimes took on strange and wondrous forms, creating an atmosphere of confusion in which courts took steps "to moderate the rigour of the law. ${ }^{.26}$

Legal complexity produced a concern among the revolutionaries that reason and equity rule American law. ${ }^{27}$ One group of revolutionaries concluded that the benefits from equity outweighed any costs wrought by more judicial discretion. Surmounting their fear of the courts of chancery, they found themselves willing to trust the judiciary to play the role as enforcers of equity.

courts in England, have by their own authority, extended their jurisdiction far beyond the limits set them ... by the laws of the land." Essays of Brutus No. 11, reprinted in 2 THE COMPLETE ANTI-FEDERALIST 417, 422 (Henry Storing ed., 1981).

23. Letter from Thomas Jefferson to Philip Mazzei (Nov. 1785), in 9 THE PAPERS OF THOMAS JEFFERSON 67, 71 (Julian P. Boyd ed., 1954) [hereinafter JEFFERSON PAPERS]. The American revolutionaries also sought to reduce judicial discretion by giving juries the power to decide law, including the right to consider a statute's constitutionality. This provided an alternative solution to the tension within republicanism between equity and judicial discretion, for it reduced judicial discretion but preserved equity by placing decisionmaking power in the hands of jurors. Juries throughout the former colonies already exercised this power to some extent. See NELSON, supra note 21, at 3-4, 8; Akhil R. Amar, The Bill of Rights as a Constitution, 100 YALE L.J. 1131, 1182-95 (1991).

24. Letter from Thomas Jefferson to Philip Mazzei, supra note 23, at 71.

25. WoOD, supra note 21, at 302. To allow "judges to set aside the law," James Madison wrote in 1788, "makes the Judiciary Department paramount in fact to the Legislature, which was never intended and can never be proper." Id. at 304.

26. Id. at 298.

27. Because so many sources of law existed in the colonies, one writer complained that "equity and justice have been nearly banished from the world." Id. at 300 . Only by resorting to rules of equity could American law wrest justice from the confusing mass of English and colonial law. However, the difficult question remained: how to secure equity and fairness in the law while containing judicial discretion? Some, like Jefferson, thought that codification could distill "the great principles of right and wrong" into "a few laws, and these simple, clear, sensible, and easy in their application to the actions of men." Id. at 300-01. Others sought to preserve the colonial jury's power to find both the facts and law as a check on judicial power. NELSON, supra note 21, at 18. 
Alexander Hamilton was one so inclined. ${ }^{28}$ In The Federalist, Hamilton expressed the fear that the legislature would pass statutes that violated fundamental principles of equity and justice. Hence, he placed the judiciary in a crucial role as the "intermediate body between the people and legislature in order, among other things, to keep the latter within the limits assigned to their authority."29

In this scheme, Hamilton saw the canons of construction as a source of law that could restrain Congress. Developed over centuries, the canons applied general principles to new circumstances, modified the law to meet specific contexts, and ultimately provided for legal change though gradual adaptation. ${ }^{30}$ The canons, Hamilton wrote, derived from "the nature and the reason" of the interpretive process. ${ }^{31}$ They existed independent of statutory authority and were inherent in the judicial function. A canon is "a rule not enjoined upon the courts by legislative provision but adopted by themselves, as consonant to truth and propriety, for the direction of their conduct as interpreters of the law."32 To Hamilton, the canons were indispensable in bringing reason to the fore of the judicial process. Because "[t]he rules of legal interpretation are rules of common sense, adopted by the courts in the construction of the laws, ${ }^{, 33}$ use of the rules depends on the text in question, and whether such use "is consistent with reason or common sense."34 By appealing to this fundamental law of reason, courts could employ the canons to check unjust congressional actions. In a sense, the canons supplemented the judiciary's check on Congress. Courts could control "unjust and partial laws" by "mitigating the severity and confining the operation of such laws. ${ }^{, 35}$ Because Congress could not be expected to moderate its own laws, Hamilton entrusted the judiciary with the duty to mitigate harsh statutes. ${ }^{36}$

28. For other views supporting more judicial discretion, see WooD, supra note 21 , at 302-05.

29. THE FEDERALIST NO. 78, at 467 (Alexander Hamilton).

30. See G. Edward White, The Marshall CourT and Cultural Change, 1815-1835, at 51-52, $118-56$ (1988).

31. THE FEDERALIST No. 78 , at 467-68 (Alexander Hamilton).

32. Id. at 468 .

33. THE FEDERALIST NO. 83, at 496 (Alexander Hamilton).

34. Id.

35. THE FEDERALIST No. 78, at 470 (Alexander Hamilton); see also DAVm F. EPSTEIN, THE POLITICAL THEORY OF THE FEDERALIST 185-92 (1984).

36. To carry out that duty, courts had to rely on two canons: that penal laws be read narrowly and that judges weigh equitable considerations in construing statutes. THE FEDERALIST No. 81, at 483 (Alexander Hamilton).

Hamilton's interpretive approach paralleled his view of judicial review. In the constitutional realm, Article III independence allows the courts to exercise judicial review. Similarly, the canons and the discretion to consider equitable factors allow the courts to restrain Congress in the statutory realm. Moreover, Hamilton's vision of statutory interpretation anticipated the methodology Chief Marshall would use in defining and applying judicial review. In Marbury v. Madison, 5 U.S. (1 Cranch) 137 (1803), and McCulloch v. Maryland, 17 U.S. (4 Wheat) 316 (1819), the Chief Justice first examined constitutional questions with a theoretical, political science-like analysis. After reaching a result based on "reason" or "common sense," Marshall then turned to the text and the canons for confirmation. See generally Paul W. Kahn, Reason and Will in the Origins of American Constitutionalism, 98 YALE L.J. 449 (1989). 


\section{B. Confusion on the Pre-Marshall Court}

The Framers' love-hate attitude toward judicial discretion and equity found expression in the early Supreme Court. Some of the Justices believed that courts should restrain their discretion by limiting themselves to a statute's text. In Priestman v. United States, the Court confronted a customs law under which the United States had seized $\$ 3899$ in watches. ${ }^{37}$ Section 19 of the law imposed forfeiture if the owner of the goods did not pay the customs duties. However, section 33 of the same act exempted goods from forfeiture if their owner did not own or operate the transporting vessel, as was the case in Priestman. Quoting Blackstone, the plaintiff argued that he fell under the section 33 exemption because of two canons of construction: judges should construe penal statutes narrowly and should harmonize all the parts of a statute. ${ }^{38}$

The Justices rejected the plaintiff's arguments and affirmed the forfeiture of his goods. In a short opinion, the Court noted that no "fair and rational construction" could include the plaintiff within section 33's exemption because such a reading would render section 19 powerless. Following a common law rule of construction known as the "whole act" rule, the Court essentially adopted the government's argument. ${ }^{39}$

In his circuit court opinion, Justice Chase also had voted to uphold the forfeiture, but for different reasons. To him, the plain meaning of section 19 clearly applied to the defendant's goods, regardless of any other sections of the act. Chase looked only to the text in his lower court opinion because of separation of powers concerns:

Similarly, Hamilton argued that the interpretation of statutes and the use of the canons had to measure up to the test of "reason." Hamilton offered two answers in response to concerns that this power would encroach on the legislature's authority. First, he believed such power did not "affect the order of the political system," i.e., it would never pose a separation of powers problem. THE FEDERALIST No. 81, at 485 (Alexander Hamilton). More significantly, he also believed that the common law rules would restrain not only Congress, but the courts as well. Hamilton wrote: "To avoid an arbitrary discretion in the courts, it is indispensable that they should be bound down by strict rules and precedents which serve to define and point out their duty in every particular case that comes before them." THE FEDERALIST NO. 78, at 471 (Alexander Hamilton). Common law precedents, and their canons of construction, would perform a dual checking function, forcing both the legislature and the judiciary to harmonize their actions with the rule of law.

37. Priestman v. United States, 4 U.S. (4 Dall.) 28 (1800). Priestman was one of the few cases of federal statutory interpretation at the time. Other such cases dealt almost exclusively with admiralty law. See 1 Charles WARREN, THE SUPREME COURT IN UNITED STATES HisTORY 91-168 (1922). In those instances, the Court often focused solely on the text of the statutes or looked to common law precedents for guidance. See, e.g., Bas v. Tingy, 4 U.S. (4 Dall.) 37 (1800) (construing Act of 1798 strictly to allow for capture of French vessels). A survey of the pre-Marshall Court's statutory interpretation cases did not uncover a single instance where a Justice resorted to legislative history.

38. 4 U.S. (4 Dall.) at 31-32.

39. Id. at 32-33. 
By the rules, which are laid down in England for the construction of statutes, and the latitude which has been indulged in their application, the British Judges have assumed a legislative power; and on the pretence of judicial exposition, have, in fact, made a great portion of the statute law of the kingdom. ${ }^{40}$

American judges, Chase said, had a "duty to conform to the expressions of the legislature, to the letter of the statute. ${ }^{, 41} \mathrm{He}$ argued for a strict reading of a statute's text, believing that a literalist approach would restrain the courts and protect the prerogatives of the legislature.

Chase applied the same literalist approach when it came to constitutional interpretation. In Calder v. Bull, the Court examined whether a Connecticut statute setting aside a local probate court decree violated the Constitution's prohibition of ex post facto laws. ${ }^{42}$ Since the statute did not fall within the literal definition of an ex post facto law, Chase upheld the statute's validity without regard to the Framers' intent. Chase wrote:

In my judgment the case $\ldots$ is not within the letter of the prohibition; and ... I am clearly of the opinion, that it is not within the intention of the prohibition; and if within the intention, but out of the letter, I should not, therefore, consider myself justified to continue it within the prohibition .... ${ }^{43}$

Because the plain text embodied the will of the legislature (via statute) or of the people (via the Constitution), Chase reasoned that courts could give force only to that text. Any unexpressed legislative intent was not controlling, and resorting to it would represent an usurpation of power by the judiciary. ${ }^{44}$

However, Chase's vision of interpretation did not rule the Court. The Priestman majority, while affirming Chase's lower court decision, did so by employing traditional statutory interpretation methods. The Court, in a unanimous and unsigned opinion, upheld the conviction so as to avoid leaving any section of the law (here, section 19) without effect, as any "fair and rational construction" would do. ${ }^{45}$ Moreover, Justice Iredell, who had challenged the

40. Id. at 30 n.1.

41. Id.

42. Calder v. Bull, 3 U.S. (3 Dall.) 386 (1798). Most discussions of Calder focus on the debate between Chase and Iredell over the place of natural law in judicial review. See GERALD GUNTHER, CASES AND Materials on Constitutional LAW 443-44 (11th ed. 1985); GeOFFrey R. StONE ET AL., Constitutional LAW 62-63 (1986); Suzanna Sherry, The Founders' Unwritten Constitution, 54 U. CHI. L. REV. 1127, 1172-73 (1987).

43. Calder, 3 U.S. (3 Dall.) at 392.

44. Cf. JOHN H. ELY, DEMOCRACY AND DISTRUST 209-11 n.41 (1980) (interpreting Calder); Kahn, supra note 36, at 474-79 (same). In the arena of federal jurisdiction, Chase argued on textual grounds that Congress could only vest the Supreme Court with original jurisdiction in the specific categories of cases outlined in Article III. Letter from Samuel Chase to John Marshall (Apr. 24, 1802), reprinted in GEORGE L. HASKINS \& HERBERT A. JOHNSON, FOUNDATIONS OF POWER: JOHN MARSHALL, 1801-1815, at 172-76 n.182 (1981).

45. Priestman, 4 U.S. (4 Dall.) at 34. 
natural law overtones of Chase's Calder opinion, countered the latter's strict approach to interpretation. In Calder, Iredell defended the primacy of congressional intent in statutory interpretation. "[T]here is no court that has power to defeat the intent of the Legislature," Iredell wrote. ${ }^{46}$

Until John Marshall's arrival at the Supreme Court, these different approaches to statutory interpretation remained in conflict. Confusion reigned due to the Court's failure to adopt any consistent procedure or rationale. This disarray, however, resulted not from intellectual unclarity, but rather from a deep-seated disagreement over how far the federal courts should go in adapting English interpretive methods to a new American context. It remained for the Marshall Court to chart a path that struck the proper balance between inherited common law methods and a new constitutional order.

\section{THE MARShall COURT}

Under Marshall, the Court resolved the tension between equity and judicial discretion in an innovative way. ${ }^{47}$ The Court made the intent of the legislature, as expressed in the text, the controlling factor in construing the laws. At the same time, the Court regularly employed the canons of construction. This approach constrained judicial discretion by limiting inquiry to the text's meaning. However, this approach preserved some flexibility in the Court's

46. Calder, 3 U.S. ( 3 Dall.) at 398-99 (citing Blackstone). Iredell continued to give a short exposition on why the legislature's actions were valid so long as they did not transgress the boundaries established by the Constitution. Courts, through their role as statutory interpreters, did not have the power to narrow or curtail legislative action, Iredell argued. Rather, the legislators "exercise the discretion vested in them by the people, to whom alone they are responsible for the faithful discharge of their trust." Id. at 399.

Iredell, however, did share Chase's separation of powers concerns. Iredell expressed this agreement in his dissent to Chisolm v. Georgia, 2 U.S. (2 Dall.) 419 (1793), which held that a South Carolina merchant could bring a suit in assumpsit against the state of Georgia. The Chisolm majority held that (1) the Court could hear the case under Article III and Section 13 of the Judiciary Act, and (2) a cause of action could lie notwithstanding state law granting Georgia immunity. Agreeing with much of the majority's reasoning, Iredell still dissented from the Court's decision to find a cause of action where state law did not provide one.

Iredell attacked the notion that the federal courts could choose a rule of decision in diversity cases-so long as no governing federal statute or constitutional provision was present. Id. at $448-49$. In essence, the majority had made what we call today an Erie mistake, by crafting a federal common law rule of liability when section 34 of the Judiciary Act (the Rules of Decision Act) called for federal courts to use state law in diversity suits. Erie R.R. v. Tompkins, 304 U.S. 64 (1938); see also Akhil R. Amar, Of Sovereignty and Federalism, 97 YALE L.J. 1425, 1469 (1987) (discussing Calder's Erie mistake). In essence, the majority had tried to fashion a federal common law rule from section 13's grant of jurisdiction to the Supreme Court over state party diversity suits. Such use of statutory interpretation to create a federal common law, Iredell feared, would represent judicial arrogation of legislative powers. "[T]he distinct boundaries of law and Legislation may be confounded, in a manner that would make Courts arbitrary, and in effect makers of $a$ new law, instead of being (as certainly they alone ought to be) expositors of an existing one." Chisolm, 2 U.S. (2 Dall.) at 448. Thus, while Iredell broke with Chase over the issue of legislative intent, he nonetheless shared his underlying concerns about preserving the separation of powers.

47. This section bases its conclusions on a review of the Marshall Court's decisions involving statutory interpretation. The author surveyed the United States Reports during the years John Marshall sat as Chief Justice. This Note discusses or cites decisions that contained significant discussions of statutory interpretation. 
equitable powers. This methodology also had the broader effect of distancing the Court from partisan politics, while still allowing it to expand the powers of the judiciary and the federal government. ${ }^{48}$

\section{A. John Marshall and Statutory Intent}

Unlike his fellow Federalist Alexander Hamilton, Marshall rejected the notion that judges should exercise broad equitable powers when construing statutes. Nor did Marshall believe that the separation of powers requires a strict, textual approach. Instead, Marshall maintained that courts should restrict their task to discovering legislative intent via the statute's text and the canons of construction. In an anonymous 1819 newspaper article, Marshall claimed he could "cite from [the common law] the most complete evidence that the intention is the most sacred rule of interpretation." ${ }^{.49}$ Other members of the Court, most notably Justice Story, fully agreed with Marshall. In his 1833 treatise on the Constitution, Story wrote, "The first and fundamental rule in the interpretation of all instruments is, to construe them according to the sense of the terms, and the intention of the parties."50

48. Scholarship on the Marshall Court, its jurisprudence, and its Chief Justice, is quite large and varied. No commentators, however, have made a systematic examination of the Marshall Court's approach to statutory interpretation. Instead, most authors have focused on the Court's constitutional decisions and on whether Chief Justice Marshall was pursuing political goals or neutral principles. Two works suggesting that Chief Justice Marshall pursued an apolitical form of legal analysis are Kahn, supra note 36 (maintaining that Marshall turned to logical reasoning on the principles and structure of the Constitution before turning to the text), and William E. Nelson, The Eighteenth-Century Background of John Marshall's Constitutional Jurisprudence, $76 \mathrm{MICH}$. L. REV. 893 (1978). The Oliver Wendell Holmes Devise History of the Supreme Court lends some support for this vision of a nonpolitical Marshall Court. See HASKINS \& JOHNSON, supra note 44, at 7 (explaining that Marshall strove to create a Court that was "a bulwark of an identifiable rule of law as distinct from the accommodations of politics"); WHITE, supra note 30 (stating that Marshall Court sought to distinguish the judicial declaration of judicial principles from partisan politics).

However, the majority of scholars have argued that the Marshall Court pursued openly nationalistic, if not Federalist Party, objectives in its decisions. See 4 ALBERT J. BEVERIDGE, THE LIFE OF JOHN MARShall 1 (1919); Felix FrankfuRTER, THE COMMERCE Clause UNDER MARShall, TANEX AND WAITE 14 (1937); 1 WARREN, supra note 37, at vii. Some have suggested that the Marshall Court acted to raise its own values above those of the electorate or even the Constitution, or that it was not above twisting the law to reach its desired result. See 1 WILLIAM W. CROSSKEX, POLITICS AND THE CONSTITUTION 50-192 (1953) (examining construction of Commerce Clause); DAVI P. CURRIE, THE CONSTITUTION IN THE SUPREME COURT: THE FRST HUNDRED YEARS, 1789-1888 (1985); Susan L. Bloch \& Maeva Marcus, John Marshall's Selective Use of History in Marbury v. Madison, 1986 WIS. L. REV. 301 (questioning Marshall's use of precedent).

49. John Marshall, A Friend of the Constitution, ALEXANDRIA GAZETTE, July 2, 1819, reprinted in JOHN MARSHALL'S DEFENSE OF MCCULLOCH V. MARYLAND 167 (Gerald Gunther ed., 1969) [hereinafter MARSHALL'S DEFENSE]. McCulloch held that the federal government had the power to establish a bank free from state tax. 17 U.S. (4 Wheat) 316 (1819). McCulloch provoked, in the words of Gerald Gunther, "[a]n extraordinary debate" in which Chief Justice Marshall waged a war with his ideological opponents over the decision through pseudonymous newspaper essays. MARSHALL's DEFENSE, supra, at 1. Marshall's articles were misprinted by his newspaper publishers. Their arguments and meaning were lost until Professor Gunther, following instructions left by Marshall in a letter to a colleague, correctly reconstructed them. Id. at $1-21$.

50. JOSEPH STORY, COMMENTARIES ON THE CONSTITUTION OF THE UNITED STATES 135 (Boston, Hilliard Gray 1833). 
Following congressional intent required courts to drop equitable considerations from their interpretations. Although he was mindful of Blackstone's and Hamilton's arguments, Marshall believed that Congress alone had the power to decide which equities a statute created. In an 1805 bankruptcy case, for example, Marshall brushed aside the plaintiff's claim that a certain interpretation would create inequities for him. ${ }^{51}$ When it came to such equitable "inconveniences," Marshall noted: "It is for the legislature to appreciate them.. ${ }^{.52}$

Marshall grounded his devotion to intent upon an assumption that Congress could and did act rationally. In a sense, he viewed Congress as if it were a party to a common law contract. Thus, Marshall would seek to divine "the mind of the legislature." ${ }^{.53}$ In his 1819 article, Marshall argued that "the great duty of a judge who construes an instrument, is to find the intention of its makers." terms. ${ }^{55}$ On the difficulties of interpretation, Marshall said: "[T]he object of language is to communicate the intention of him who speaks." ${ }^{956} \mathrm{He}$ saw Congress speaking, but only in a statutory tongue. ${ }^{57}$

This assumption led Marshall to presume that Congress would always act in accordance with existing laws. Marshall argued that courts should interpret statutes so as to avoid overriding individual rights or the Constitution. Unless

51. United States v. Fisher, 6 U.S. (2 Cranch) 358 (1805).

52. Id. at 390.

53. See, e.g., Pennington v. Coxe, 6 U.S. (2 Cranch) 33, 52 (1804) ("[A] law is the best expositor of itself, that every part of an act is to be taken into view, for the purpose of discovering the mind of the legislature." (emphasis added)). In the same case, Marshall also referred to a statute as the object of "the whole attention of the legislature." Id. at 55.

54. MARSHALL'S DEFENSE, supra note 49, at 168-69.

55. Commentators have argued that 18th-century usage allowed for two types of intent: that of a document's framers and that of a document itself. See Powell, Original Understanding, supra note 10, at 895-96. A statute's intent could denote what a judge, using the "artificial reason and judgment of law," derived from the text, rather than the subjective purposes of its drafters. Prohibitions del Roy, 77 Eng. Rep. 1342, 1343 (K.B. 1608), quoted in Powell, Original Understanding, supra note 10, at 896 \& n.55. But see Berger, "Original Intention," supra note 10 (arguing that intent of document's framers was goal of 19thcentury interpretation).

56. MARSHALL'S DEFENSE, supra note 49 , at 168 .

57. This argument may explain why 19th-century courts never resorted to "legislative history" when interpreting statutes. If courts conceived of a legislature as a single entity that could "speak" and turn its "attention" to discrete "objects," then only statements made through the legislature's statutory "voice" could represent its collective wishes. Of course, a lack of committee reports and other legislative materials could also explain the failure to cite to legislative history. Legislative history at the time was particularly unreliable. ALAN P. GRIMES, DEMOCRACY AND THE AMENDMENTS TO THE CONSTITUTION 9 (1987). The Annals of Congress were not published until 1834, although somewhat unreliable reports did exist from the time of the first Congress. Powell, Modern Misunderstanding, supra note 10, at $1536 \mathrm{n} .87$.

Courts also may have sneaked peeks at the legislative history without citing it. Marshall may have been guilty of glancing at the legislative history. See McCulloch v. Maryland, 17 U.S. (4 Wheat.) 316, 402 (1819) (referring to events surrounding passage of bill incorporating the Second Bank of the United States). In his 1819 newspaper defense of $M c C$ ulloch, Marshall reviewed the legislative history of the first bank bill, describing "the debates in the first congress" between the "opponents" and the "friends" of the proposal. Marshall even referred to executive branch deliberations, quoting the debate between Treasury Secretary Hamilton and Secretary of State Jefferson over the constitutionality of the bill. MARSHALL'S DEFENSE, supra note 49 , at $175-77$. 
Congress explicitly said so, it would not pass a law "[w]here rights are infringed, where fundamental principles are overthrown, where the general system of the laws is departed from." 58 Similarly, in the realm of foreign affairs Marshall suggested that Congress would not pass statutes that violated international law. Such statutes "ought never to be construed to violate the law of nations if any other possible construction remains. ${ }^{.59}$ These canons assumed that Congress was fully aware of the legal context surrounding its statutes and would seek to avoid conflict with it. ${ }^{60}$

For Marshall, the importance of discovering legislative intent justified using differing interpretive techniques in different cases. "Where the mind labours to discover the design of the legislature, it seizes every thing from which aid can be derived."61 Marshall recognized that words often had different meanings depending upon the context. "Such is the character of human language, that no word conveys to the mind, in all situations, one single definite idea; and nothing is more common than to use words in a figurative sense." 62 However, Marshall wedded this appreciation of context to a methodology that focused on the statute's text.

\section{B. Deploying the Canons in the Marshall Court}

The canons of construction served the Marshall Court as the most useful, and most used, tools for introducing context into the search for congressional intent. The canons provided interpretive techniques developed over centuries of the common law. "[T]hose rules for construing statutes," Marshall wrote in 1823, "are dictated by good sense, and sanctioned by immemorial usage, which require that the intent of the Legislature shall have effect." ${ }^{163}$ However, Marshall always first consulted the ordinary meaning of the terms in a statute. Only then would he turn to the canons to provide confirmation for his reading of the text. Throughout, the statutory language served as the foundation for his analysis.

58. United States v. Fisher, 6 U.S. (2 Cranch) 358, 390 (1805).

59. Murray v. The Schooner Charming Betsy, 6 U.S. (2 Cranch) 64, 118 (1804). For a further discussion of this canon, see Ralph G. Steinhardt, The Role of International Law As a Canon of Domestic Statutory Construction, 43 VAND. L. REV. 1103 (1990).

60. Assumption of congressional rationality also underlies the canon of in pari materia, which requires courts to look at other statutes when construing ambiguous terms. In pari materia holds that Congress is aware of the body of statutory law when it passes a statute.

61. Fisher, 6 U.S. (2 Cranch) at 386.

62. McCulloch v. Maryland, 17 U.S. (4 Wheat) 316,414 (1819).

63. The Mary Ann, 21 U.S. (8 Wheat) 380, 387 (1823) (construing Slave Trade Act of 1807 to apply only to cargo vessels of 40 tons or more). 


\section{United States v. Fisher}

United States v. Fisher provides the Marshall Court's most extensive discourse on interpretive methodology ${ }^{64}$ In Fisher, the United States attempted to attach the property of Peter Blight, who owed the government money as the endorser of a foreign bill of exchange held by the Treasury Department. Blight, however, had filed for bankruptcy in Rhode Isiand, and his assets were already assigned to creditors. The case turned on whether the United States had a right to receive money from Blight's estate prior to the other creditors, who held their assignment under state law. ${ }^{65}$

The United States claimed that federal bankruptcy statutes authorized it to receive its claim before private or state creditors. The government relied upon section 5 of the Bankruptcy Act of March 3, 1797, which stated that when "any revenue officer, or other person hereafter becoming indebted to the United States ... . shall become insolvent ... the debt due to the United States shall be first satisfied." person" referred to government officials accountable for public money or to all citizens. Blight was not a government employee, but the government argued that the statute extended to all persons, whether public officials or not.

Riding circuit in Pennsylvania, Justice Washington rejected the government's arguments and held that the federal bankruptcy law did not grant the United States an absolute preference over other creditors. Washington's ruling relied upon a "limited interpretation" of section 5 that started with the assumption that a literal interpretation of "other person" would prove unfair to all creditors. ${ }^{67}$ If the United States could gain preference in all bankruptcy cases, Washington argued, any creditor dealing with a debtor "does it at the peril of having his debt postponed to that of the United States." Such an unfair result would destroy "all confidence between man and man." Washington strained to "see if such consequences may not be avoided, by a fair and reasonable construction." $" 68$

Washington began by looking at the title of the statute, which read: "An act to provide more effectually for the Settlement of Accounts between the United States, and Receivers of public Money." ${ }^{\circ 9}$ From this, Washington interpreted Congress' purpose as governing only "receivers of public money" who go bankrupt. Next, Washington looked at the first four sections of the act, which set out a cause of action, established rules of evidence, designated places of trial, and outlined legal defenses involving suits by private creditors against

64. United States v. Fisher, 6 U.S. (2 Cranch) 358 (1805).

65. Id. at 385; see also United States v. Fisher, 25 F. Cas 1087 (C.C.D. Pa. 1803) (No. 15,103), rev'd, 6 U.S. (2 Cranch) 358 (1805).

66. Act of Mar. 3, 1797, ch. 20, $\S 5$, 1 Stat. 512, 515 (emphasis added).

67. Fisher, $25 \mathrm{~F}$. Cas at 1088.

68. Id.

69. 1 Stat. at 512 . 
revenue officers or holders of public money. Since these sections referred only to a "revenue officer or other person accountable for public money," Washington concluded that Congress also intended to limit section 5 to that class. $^{70}$ Finally, Washington looked at section 62 of the Bankruptcy Act of 1800 , which declared that "nothing contained in this law shall, in any manner, effect the right of preference to prior satisfaction of debts due to the United States as secured or provided by any law heretofore passed."71 Washington reasoned that Congress would not have included such a phrase if the 1797 Act had already granted the United States preference in all cases. ${ }^{72}$

On appeal, the defendants essentially repeated Washington's statutory arguments. ${ }^{73}$ Writing for the Court, Marshall praised the defendants' reliance on the canons of statutory interpretation. "On the abstract principles which govern courts in construing legislative acts, no difference of opinion can exist. ${ }^{374}$ The Chief Justice agreed that harmonizing all the sections of an act, looking to the title of act, and comparing the act to other statutes were all "well established principle[s]." $"$

Marshall, however, overturned the circuit decision because it had failed to seek congressional intent by examining the plain terms of the statutory language. In his circuit court opinion, Washington explicitly had sought an interpretation that avoided the unwise policy of giving the United States priority in all bankruptcy cases. ${ }^{76}$ Marshall criticized this approach, declaring that courts should not seek to make such policy judgments:

But where only a political regulation is made, which is inconvenient, if the intention of the legislature be expressed in terms which are sufficiently intelligible to leave no doubt in the mind when the words are taken in their ordinary sense, it would be going a great way to say that a constrained interpretation must be put upon them, to avoid an inconvenience which ought to have been contemplated in the legislature .... ${ }^{77}$

70. Fisher, 25 F. Cas. at 1088-89.

71. Bankruptcy Act of 1800 , ch. $19, \S 62,2$ Stat. 19, 36 .

72. Fisher, 25 F. Cas at 1089.

73. The defendants also tacked on a constitutional argument challenging Congress' power to give the United States priority in all cases. "If liens general or specific, if judgments and mortgages are to be set aside by the prerogative of the United States, it will be to impair the obligation of contracts by an ex post facto law," argued respondent's counsel. Fisher, 6 U.S. (2 Cranch) at 379. At the very end of Fisher, almost as an afterthought, the Court dismissed the constitutional claim by holding that Congress had the power to pass such a statute under the Necessary and Proper Clause. Id. at 396-97. Moreover, Article I, Section 8 of the Constitution gives Congress the power "[t]o establish . . . uniform Laws on the subject of Bankruptcies throughout the United States." U.S. CONST. art. I, \& 8, cl. 4.

74. Fisher, 6 U.S. (2 Cranch). at 386. Washington, while taking no part in the case, still took the opportunity to reiterate his views at length. He agreed that "[t] hese rules [of construction] are not merely artificial; they are as clearly founded in plain sense, as they are certainly warranted by the principles of common law." Id. at 400.

75. $I d$. at 386.

76. Fisher, $25 \mathrm{~F}$. Cas. at 1088.

77. Fisher, 6 U.S. (2 Cranch) at 390. 
And, Marshall declared, the plain language of section 5 clearly included the case at hand. The "natural sense of words" used by Congress extended section 5 to "all debtors generally." Specifically, he pointed to the use of the phrase "person accountable for public money" in the first section and the reference to such persons in the following three sections, but its replacement with "other person ... becoming indebted to the United States" in section 5. "This change of language strongly implies an intent to change the object of legislation.".78

Since the plain meaning of the language was clear, the Court rejected the tools of construction relied upon by respondents and the circuit court. "[The language] appears, to the majority of the court, to be too explicit to require the application of those principles which are useful in doubtful cases." ${ }^{.79}$ Nonetheless, Marshall argued that the canons of construction-properly applied-reinforced, rather than undermined, the Court's reading. Since section 5 dealt not with judicial procedure, but with the preference of the United States over other creditors, Marshall concluded that "the fifth section is totally unconnected with those which precede it." ${ }^{\text {"80 }}$ Moreover, Marshall found that examining other statutes in the U.S. Code (a practice known as in pari materia) fortified a broad reading of section 5. Looking at three earlier bankruptcy acts, he found that section 5 followed a trend expanding the United States' rights to preference as a creditor. ${ }^{81}$

Fisher illustrates the Marshall Court's general approach to statutory interpretation. First, the Court would examine the words of the statute. If the words were clear, then the Court would apply their plain or commonsense meaning. However, as often happens, the words might prove too vague or general. In that case, the Court would turn to the other parts of the act under the theory "[t]hat a law is the best expositor of itself, that every part of an act is to be taken into view, for the purpose of discovering the mind of the legislature." ${ }^{82}$ When examining other sections of an act, the Court would search for specific words to restrict the meaning of the general words in question. ${ }^{83}$ Instead of seeking guidance from legislative history or legislators' remarks, the Court would rely upon the commonsense meaning of the terms Congress chose. And finally, the Court would consistently focus the process of interpretation upon divining congressional intent. In Fisher, Marshall forcefully rejected the circuit court's attempts to mold a construction of section 5 that would avoid unwise policies.

78. Id. at $387-88$.

79. Id. at 389.

80. Id.

81. Id. at 393-95.

82. Pennington v. Coxe, 6 U.S. (2 Cranch) 33, 52 (1804).

83. The canon noscitur a sociis requires judges to look at the words and clauses surrounding the text in question for meaning. Another canon, ejusdem generis, which translates as "of the same kind, class, or nature," looks to other words and clauses for restrictions on general, ambiguous phrases. See 2A JABEZ G. SUTHERLAND, STATUTES AND STATUTORY CONSTRUCTION $\$ 47.17$, at 166 (Norman J. Singer ed., 4th ed. 1984). 
Instead, he saw his task as simply enacting congressional intent; he left policy decisions "for the legislature to appreciate." 34

\section{United States v. Wiltberger}

While Marshall preferred to interpret statutory language by its plain, everyday meaning, he always consulted the statute's structure to confirm his reading. United States $v$. Wiltberger ${ }^{85}$ illustrates his approach. In Wiltberger, the defendant, a ship's master, had killed Peters, one of his seamen, with an oak stave. ${ }^{86}$ The homicide took place on board an American merchant vessel floating on the Tigris River in China. ${ }^{87} \mathrm{~A}$ federal jury convicted Wiltberger under a 1790 statute establishing punishments for serious federal crimes.

Unsure whether the homicide fell under its jurisdiction, the circuit court certified the case to the Supreme Court. Article I of the Constitution clearly granted Congress the power to regulate felonies committed on the oceans, ${ }^{88}$ while Article III gave the federal judiciary exclusive jurisdiction over all maritime and admiralty cases. ${ }^{89}$ But it remained unclear whether Congress intended section 12 of the 1790 act, which punished manslaughter committed on "the high seas," to reach manslaughter committed on a river."

The United States argued that Congress indeed had intended the 1790 act to reach this crime. Referring to section 8 of the 1790 act, the government claimed that Congress had extended federal jurisdiction to murder or robbery committed "upon the high seas, or in any river, haven, basin or bay." Unfortunately for the government, Congress had failed to append "river, haven, basin or bay" to the term "high seas" in section 12. Nevertheless, the Attorney General argued that since Congress had included such a description in its provision on murder, "it was natural that the legislature should suppose the language engrafted into a subsequent section on a subject of the same class."91

Writing for the Court, Marshall rejected this claim and focused on section 12's statutory language. The plain meaning of "high seas," he argued, simply did not include a river.

If the words be taken according to the common understanding of mankind, if they be taken in their popular and received sense, the "high seas," if not in all instances confined to the ocean which washes a

84. Fisher, 6 U.S. (2 Cranch) at 390.

85. 18 U.S. (5 Wheat.) 76 (1820).

86. United States v. Wiltberger, 28 F. Cas. 727, 729 (C.C.E.D. Pa. 1819) (No. 16,738).

87. 18 U.S. (5 Wheat.) at 76.

88. "The Congress shall have Power ... To define and punish Piracies and Felonies committed on the high Seas, and Offenses against the Law of Nations . . . ." U.S. CoNST. art. I, § 8, cl. 10.

89. "The judicial Power shall extend . . . to all Cases of admiralty and maritime Jurisdiction . . . ." U.S. CoNST. art. III, $\S 2$, cl. 1.

90. Act of Apr. 30, 1790, 1 Stat. 113.

91. Wiltberger, 18 U.S. (5 Wheat.) at $91-92$. 
coast, can never extend to a river about half a mile wide, and in the interior of a country. ${ }^{92}$

Clear language alone, Marshall ruled, should decide the matter. "The case must be a strong one indeed, which would justify a Court in departing from the plain meaning of words ... in search of an intention which the words themselves did not suggest. ${ }^{, 93}$ No such case was present.

Yet Marshall did not stop there. As in Fisher, he consulted the canons of construction to confirm his reading of the text. Both section 3 and section 7 of the 1790 act, which concerned murder and manslaughter committed on land, gave a complete and identical list of all the places where such crimes would trigger federal jurisdiction. Marshall took this to mean that if Congress had intended section 12's provisions on manslaughter to extend as far as section 8 's on murder, then it simply would have repeated "river, haven, basin or bay" in section $12 .{ }^{94}$

Moreover, section 9, which stated that no citizen acting under the commission of a foreign authority would be spared the death penalty for robbery and murder, explicitly referred to section 8 . If Congress had intended section 12 to refer back to section 8 , it would have said so-as it had in section 9 . Instead, Marshall wrote, "the legislature has not referred for a description of place to any previous parts of the law, but has inserted a description, and by so doing, has materially varied the obvious sense of the section." other sections of the act also made a full listing of places, he decided that " $[t]$ he conclusion seems irresistible, that Congress has not in this section inserted the limitation of place inadvertently; and the distinction which the legislature has taken, must of course be respected by the Court."96

In Wiltberger the Marshall Court employed the same interpretive techniques used in Fisher. Marshall concentrated on the plain, commonsense meaning of the terms Congress used in the statute. He took the precise words as the most reliable indications of congressional intent-an intent he assumed to be rational. To confirm his reading, he then turned to different canons of statutory interpretation. This involved examining other sections of the act and often required looking at similar statutes on related subjects. Although the Court did not need to resort to other canons of construction in Fisher or Wiltberger, it often did so in other cases.

\footnotetext{
92. Id. at 94 .

93. Id. at 96 .

94. Id. at 99.

95. Id. at 101 .

96. Id. at 104 .
} 


\section{Other Statutory Cases in the Marshall Court}

In other contexts, the Marshall Court employed several other canons that focused on a statute's text and structure. These canons sought to infer meaning from the placement of words and their relationship to the statute's other provisions. If that failed, the Court resorted to canons that drew meaning from other statutes. Finally, the Court sometimes turned to rules of construction that made substantive policy presumptions concerning different types of statutes. In applying these canons, the Court consistently attempted to effectuate congressional intent as enunciated in the statutory text.

The Court often examined a statute's title to discern its scope and purpose. "The title of an act cannot control its words, but may furnish some aid in showing what was in the mind of the legislature." ${ }^{.97}$ In addition, the Court looked at enumerations the statute did not make to infer elements which the legislature specifically excluded from the law. ${ }^{98}$ Story applied this canon in the 1828 case Minor v. Mechanics Bank ${ }^{99}$ to hold that by failing to require a bank to maintain a minimum amount of capital, a statute did not intend to establish such a requirement.

A third canon, today known as the "whole act" rule, required that a court give force to all provisions of a statute without diminishing the power of any provision. In Buel v. Van Ness, Justice Johnson applied this rule to hold that federal question jurisdiction under section 25 of the Judiciary Act of 1789 did not require a minimum amount in controversy. ${ }^{100}$ Johnson reached this result by comparing section 25 to section 22 of the Judiciary Act, which explicitly set out minimum amount requirements for diversity cases. Johnson concluded that since Congress had not included similar requirements in section 25 , it did not want appeals from state court decisions to be so limited. ${ }^{101}$ The Marshall Court generally relied upon the whole act rule, perhaps because, by assuming the existence of a rational legislature, it confirmed the value of a search for legislative intent. ${ }^{102}$

97. United States v. Palmer, 16 U.S. (3 Wheat.) 610,631 (1818) (Marshall, C.J.). The title of the statute at issue read: "an act for the punishment of certain crimes against the United States." Marshall used this as evidence that Congress did not intend the statute to apply to crimes committed by American citizens against "the human race." See discussion infra notes 120-22 and accompanying text.

98. This canon, known as expressio unius est exclusio alterius, roughly translates as "inclusion of one thing indicates exclusion of the other."

99. 26 U.S. (1 Pet) 46, 64-65 (1828).

100. Buel v. Van Ness, 21 U.S. (8 Wheat.) 312, 322-24 (1823) (discussing 1 Stat. 73); see also Akhil R. Amar, The Two-Tiered Structure of the Judiciary Act of 1789, 138 U. PA. L. REV. 1499 (1990) (comparing $\S 22$ of Judiciary Act of 1789 to $\S 25$ to demonstrate that federal question jurisdiction requires no minimum amount in controversy).

101. 21 U.S. (8 Wheat) at 322-23.

102. For example, Marshall applied the whole act rule in Postmaster-General v. Early, 25 U.S. (12 Wheat.) 136 (1827), to hold that the Postmaster-General could sue for the recovery of bonds given by postal fee collectors. Section 29 of the statute allowed the Postmaster General to sue for debts owed by collectors, but did not empower the Postmaster to take bonds to secure such debts. Act of Apr. 30, 1810, ch. $262, \S 29$. However, sections 22 and 31 of the Act outlined procedures for enforcing such bonds, leading Marshall 
To supplement these intrinsic aids to interpretation, the Court always turned to extrinsic sources. ${ }^{103}$ As seen in Fisher, the Court looked to the legal context of the statute in question-in that case, similar statutes-to give meaning to ambiguous laws. Turning to other statutes in pari materia appears to have been one of the most employed rules of construction on the Court. ${ }^{104}$ The Court also relied upon the common law as another extrinsic aid for legal definitions and meaning. ${ }^{105}$

Finally, the Court applied a third tier of canons based on substantive policy presumptions. These rules called for liberal or strict constructions depending on the subject matter of the statute. For example, the Court held in Ross v. Doe that when Congress intends "to confer a bounty on a numerous class," the Court must construe the statute broadly to "effect the liberal intentions of the legislature."106 This canon found its roots in the common law rule that remedial statutes are to be liberally construed to effect their purposes. The most respected of these canons, the rule of lenity, stated that courts should interpret penal statutes strictly in favor of the defendants due to "the tenderness of the law for the rights of individuals." 107 "The rule that penal laws are to be construed strictly, is perhaps not much less old than construction itself," Marshall wrote. ${ }^{108}$ Sometimes, the Court even extended this doctrine to cases outside the criminal context. In Sixty Pipes of Brandy, for example, the Court held that the Duty Act of 1799 , a civil statute, imposed such harsh penalties on violators that it warranted a narrow construction. ${ }^{109}$

If the Court felt that the legislative intent was clear, it would go so far as to rely on that intent to resolve conflicting language in the same statute. In Ross

to conclude that Congress intended "debts" to include bonds. Marshall said of the whole act rule and its utility in discovering legislative intent:

There is always difficulty in extending the operation of the words beyond their plain import; but the cardinal rule of construction is, that where any doubt exists, the intent of the legislature, if it can be plainly perceived, ought to be pursued. It is also a rule, that the whole law is to be taken together, and one part expounded by any other, which may indicate the meaning annexed by the legislature itself to ambiguous phrases.

25 U.S. (12 Wheat.) at 152; see also The Mary Ann, 21 U.S. (8 Wheat.) 380, 388-89 (1823).

103. In the scholarship on statutory interpretation, "intrinsic aids" are rules that are based upon the composition, syntax, and structure of a statute. See WILLIAM N. ESKRDGE, JR. \& PHIIIP P. FRICKEY, CASES AND MATERIALS ON LEgISLATION: STATUTES AND THE CREATION OF PUBLIC POLICY 639-46 (1988).

104. See Ross v. Doe, 26 U.S. (1 Pet) 655 (1828); The Star, 16 U.S. (3 Wheat) 78 (1818) (neither Prize Act of 1812 nor Salvage Act of 1800 permits recovery by original owner of vessel recaptured from enemy); United States v. Palmer, 16 U.S. (3 Wheat.) 610 (1818); The Thomas Gibbons, 12 U.S. (8 Cranch) 421 (1814) (President has statutory authority to order capture of British merchant vessels); Pennington v. Coxe, 6 U.S. (2 Cranch) 33 (1804).

105. See Palmer, 16 U.S. ( 3 Wheat.) at 630 (construing term "robbery" by referring to its common law definition).

106. Ross v. Doe, 26 U.S. (1 Pet.) 655, 667 (1828).

107. United States v. Wiltberger, 18 U.S. (5 Wheat.) 76, 95 (1820) (statute outlawing crimes on high seas did not reach acts committed on Chinese river).

108. Id.

109. Sixty Pipes of Brandy, 23 U.S. (10 Wheat) 421 (1825). Johnson, writing for the Court, absolved from charges of evading the Act a merchant who had mixed and relabeled imported liquors. 
v. Doe, ${ }^{110}$ the Court examined an 1803 statute granting Mississippi settlers the land they occupied "on that day of the year seventeen hundred and ninetyseven, when the Mississippi territory was finally evacuated by the Spanish troops." 111 Unfortunately for the settlers, the Spanish stayed put until 1798, undermining the validity of claims under the statute. Looking at the statutory language and purpose, Justice Trimble found that the Act's "manifest general intent" was "to confer a bounty upon" the settlers who remained until the Spanish left. ${ }^{112}$ Thus, the date of 1797 "must be rejected as inconsistent with the main scope and general intent of the law."113

The focus on legislative intent distinguished the Marshall Court's approach from earlier versions. The Court's methodology broke with those republicans who wanted to restrict interpretation solely to the statutory text. The Court felt quite comfortable employing a wide range of intrinsic and extrinsic aids to uncover a law's meaning. Nor did it hesitate to use policy-oriented canons when it saw fit. But unlike Hamilton and Blackstone, the Court saw little room for equitable concerns in statutory interpretation. Instead, the canons became a means for the Court to reach its interpretive goal: discerning the intent of Congress. The canons played a crucial role by providing tools-grounded, as the Court's members believed, in legal reason and tradition-that linked statutory text and structure to congressional intent.

\section{The Strategy Behind the Canons}

A number of important policies emerge from the Marshall Court's use of the canons. Through its statutory interpretation cases, the Court sought to impose uniformity upon American law. Perhaps more importantly, these cases also show the Court trying to bolster its image as a nonpartisan institution. ${ }^{114}$ Finally, the cases show the Court working to enhance the power of the judiciary and the federal government. The canons granted the Court enough flexibility to achieve its ideological goals without breaching the limits set by its interpretive methodology.

First, the canons performed a nationalizing function by bringing an orderly methodology to statutory interpretation. The Court saw the canons as fundamental "principles," discoverable through reason, justice, and custom. Their scientific application would bring clarity and intelligibility to cases, and would make American law more uniform, predictable, and systematic. ${ }^{115}$ By

110. 26 U.S. (1 Pet.) 655.

111. Act of Mar. 3, 1803, ch. 27, 2 Stat. 229, quoted in Ross, 26 U.S. (1 Pet.) at 667.

112. Id.

113. Id. at 668 .

114. See generally Nelson, supra note 48 , at $932-60$.

115. The movement to make law a more scientific discipline manifested itself in the outpouring of legal treatises in the early 19th century. Joseph Story, who held a post at Harvard as Dane Professor of Law, was a main proponent of this movement both in academia and on the Court. See STORY, supra note 50. Several 
the 1820 's, legal scholars argued that all judges should adopt the Court's systematic approach to statutory interpretation. ${ }^{116}$

Second, the canons helped reinforce an image of the federal judiciary as a nonpartisan discoverer of the law. Worries abounded among the Founders - especially the Anti-Federalists - that the judiciary would use its discretion either to further the political interests of the government or to usurp legislative power. ${ }^{117}$ The Court sought to deflect these criticisms by following the canons. These rules appeared to constrain judicial discretion by limiting a court's freedom to construe a statute's meaning. Judges would make decisions by following these impartial rules, leaving little room for their own political agendas. ${ }^{118}$

The canons also discouraged the Marshall Court from passing on the wisdom of congressional policies. Referring to other statutes in pari materia, for example, forced the Court to respect Congress' general policies as expressed in the entire body of statutory law. In The Thomas Gibbons, Justice Story said of an in pari materia interpretation: "In giving this construction, therefore, we are satisfied that we ... do not contravene any policy avowed by the government itself." ${ }^{\text {"119 }}$ Hamilton and others had urged the judiciary to mitigate harsh statutes in an effort to give the judiciary a significant checking role on Congress in the statutory as well as the constitutional realm. The Court expressly rejected this expansive role, limiting its interpretive powers to those of the canons. "[W]e are not at liberty to entertain any discussions in relation to the policy of the government," Story wrote in an 1818 case construing the Prize Act of 1812. "We must interpret, therefore, this clause of the prize act by the general rules of construction applicable to all statutes." 120

By adopting the canons, the Court appeared to defer to the political branches whenever policy issues arose. United States v. Palmer, for example, required the Court to interpret a 1790 statute making high seas murder, robbery, "or any other offence, which, if committed [on land] would ... be punishable with

other treatises also sought to systematize and rationalize American law. See generally NATHAN DANE, A GENERAL ABRIDGEMENT AND DIGEST OF AMERICAN LAW (Boston, Cummings, Hilliard 1823); JAMES KENT, COMMENTARIES ON AMERICAN LAW (N.Y., O. Helsted 1826); ST. GEORGE TUCKER, BLACKSTONE'S COMMIENTARIES: WITH NOTES OF REFERENCE, TO THE CONSTITUTION AND LAWS OF THE UNITED STATES; AND OF THE COMMONWEALTH OF VIRGINIA (Phila., Birch \& Small 1803).

116. $1 \mathrm{KENT}$, supra note 115 , at $429-438$.

117. Some Framers of the Constitution were concerned that the federal courts might follow what they saw as the example of England, where the judges were perceived as delivering partisan decisions. See HASKINS \& JOHNSON, supra note 44; WHITE, supra note 30, at 1-75; Nelson, supra note 48.

118. This resonated with strains in republican thought that had sought to reduce judicial discretion and power. "[T]he Laws of every State ought always to be fixed, [and] certain," and "every possible Case . . . [be] settled in a Precedent, leav[ing] nothing, or but little to the arbitrary Will or uninformed Reason of Prince or Judge." NELSON, supra note 21, at 19. Nelson notes that "Americans of the prerevolutionary period expected their judges to be automatons who mechanically applied immutable rules of law to the facts of each case." Id.

119. The Thomas Gibbons, 12 U.S. (8 Cranch) 421, 431 (1814).

120. The Star, 16 U.S. ( 3 Wheat) $78,88-89$ (1818). 
death" a capital crime. ${ }^{121}$ Writing for the majority, Marshall interpreted the statute to mean that robbery would be a capital crime on the high seas, even if it were not one on land. Of other considerations, such as lenity toward criminals or jurisdiction over foreign nationals, Marshall noted: "[S]uch questions are generally rather political than legal in their character. They belong more properly to those who can declare what the law shall be."122 Similarly, in United States v. Fisher, Marshall described the law in question as a "political regulation" whose costs and benefits "ought to have been contemplated in the legislature when the act was passed."123 Again in United States v. Wiltberger, he rejected the argument that the Court should interpret a statute strictly. "[T]he power of punishment is vested in the legislative, not in the judicial department. It is the legislature, not the Court, which is to define a crime, and ordain its punishment." ${ }^{, 124}$ In essence, Marshall used the canons to keep the Court focused on nonpolitical legal questions and away from policy spheres properly inhabited by the political branches. ${ }^{125}$

Nevertheless, allegiance to the canons expanded the federal judiciary's powers. Finding certain "principles" of construction established a uniform, national system of interpretation, one determined by the Supreme Court and other federal-but not state-courts. ${ }^{126}$ Moreover, the common law rules of interpretation still granted judges a wide area of discretion. Courts could decide which canons to apply and in what order, and which canons to disregard. In cases in which the Court decided that the statutory language clearly expressed congressional intent, it never needed to consult the canons. It was still within the judiciary's discretion to decide when to employ the canons or when the language was clear enough to leave them aside..$^{127}$

121. United States v. Palmer, 16 U.S. (3 Wheat) 610, 626 (1818) (quoting Act of Apr. 30, 1790, ch. 9, 1 Stat. 112). Defendants, who had committed robbery on the high seas, argued that the statute did not make robbery a capital crime because it was not punishable by death on land.

122. Id. at 634. However, Chief Justice Marshall set the defendants free on the secondary grounds that the statute, which prohibited piracy committed against "any person," did not extend to acts against Spanish citizens on a Spanish ship. This interpretation relies on the vision of a rational Congress since it assumes that Congress would not attempt the constitutionally problematic move of extending federal jurisdiction to crimes committed by foreign nationals on foreign ships. President Adams criticized this second holding for reducing congressional power to combat piracy. See G. Edward White, The Marshall Court and International Law: The Piracy Cases, 83 AM. J. INT'L L. 727, 731 (1989).

123. United States v. Fisher, 6 U.S. (2 Cranch) 358,390 (1805).

124. United States v. Wiltberger, 18 U.S. ( 5 Wheat) 76,95 (1820).

125. Cf. Nelson, supra note 48 , at $932-60$.

126. Before Marshall took office, some state courts struck down statutes they felt violated "reason" or "common right." See Bowman v. Middleton, 1 S.C.L. (1 Bay) 252 (1792); Ham v. M'Claws \& Wife, 1 S.C.L. (1 Bay) 93 (1789). Other courts sought to interpret statutes narrowly. See supra text accompanying notes 37-41 (discussing Priestman v. United States, 4 U.S. (4 Dall.) 28 (1800)).

127. Scholars today see the canons as a disorderly collection of common sense rules that are consistently used by the courts and consistently criticized by scholars. See Eskridge, supra note 9, at 662; see also 2A SUTHERLAND, supra note 83; Richard A. Posner, Statutory Interpretation In the Classroom and in the Courtroom, 50 U. CHI. L. REV. 800, 805-14 (1983); Cass R. Sunstein, Interpreting Statutes in the Regulatory State, 103 HARV. L. REV. 405, 411-12, 423-24, 451-60 (1989). 
Such discretion gave the Court freedom to build the institutional power of the Court and the federal government, as demonstrated by the substantive results of several of its opinions. In Buel v. Van Ness, for example, the Court interpreted section 25 of the Judiciary Act of 1789 to confirm its broad appellate power of review over state court decisions. ${ }^{128}$ In Fisher, the Court broadly construed legislation giving the United States preference in bankruptcy proceedings. ${ }^{129}$ In Postmaster-General v. Early, the Court liberally interpreted an 1815 statute to give the Postmaster-General the power to accept and sue to recover bonds. ${ }^{130}$ In Palmer, the Court expanded statutes setting criminal penalties for crimes committed on the high seas. ${ }^{131}$ Other cases broadly construed statutes in admiralty law, commerce, and land grants. ${ }^{132}$ Thus, the Marshall Court's jurisprudence on statutory interpretation contained a powerful ideological component, one that sought simultaneously to remove the Court from politics and to expand federal power.

\section{CONCLUSION}

Like courts today, the Framers and the members of the Marshall Court frequently had to construe ambiguous and unclear statutes. Faced with Americans' paradoxical love-hate relationship with judicial discretion and equity, the Marshall Court responded by adopting an approach that emphasized a statute's text, structure, and legal context. In the process, the Court resisted the temptation to exercise broad equitable powers and focused its efforts on determining congressional intent.

This examination lends support to recent work showing that the Marshall Court was not as political as conventional wisdom has taught. ${ }^{133}$ In the statutory context, the Court adopted the canons of construction in part to remove itself from the policy spheres properly inhabited by the other branches. Moreover, employing the canons allowed the Court to bolster its role as a nonpartisan discoverer of the law. In its statutory interpretation cases, the Court was more concerned with developing certain, predictable principles than with reaching a result in keeping with Federalist ideology. The Court's interpretive methodology, however, did provide it with a degree of maneuverability to advance the power of the federal government when the opportunity arose.

Finally, the Marshall Court's jurisprudence provides a glimpse of how those who followed the Framers modified familiar English institutions to build a

128. See Buel v. Van Ness, 21 U.S. (8 Wheat.) 312 (1823); supra text accompanying notes 100-01.

129. See United States v. Fisher, 6 U.S. (2 Cranch) 358 (1805); supra notes $64-84$ and accompanying text.

130. See Postmaster-General v. Early, 25 U.S. (12 Wheat) 136 (1827); supra note 102.

131. See supra notes 121-23.

132. The Thomas Gibbons, 12 U.S. (8 Cranch) 421 (1814); Minor v. Mechanics Bank, 26 U.S. (1 Pet.) 46 (1828); Ross v. Doe, 26 U.S. (1 Pet.) 655 (1828).

133. See, e.g., HASKINS \& JOHNSON, supra note 44; Nelson, supra note 48. 
wholly new constitutional environment. Chief Justice Marshall borrowed the canons of construction from the common law, but adapted them to the goal of discovering congressional intent. Although Marshall took that goal as constitutionally required, he did not feel that the constitution or statutes required him to use a particular methodology to reach that end. Instead, his opinions suggest that the judiciary had the inherent discretion to decide how to interpret statutes. Marshall, then, appealed to judicial reason and custom, which he found in the common law, for rules of interpretation. In this way, it was "emphatically the province and duty of the judiciary" not only "to say what the law is,"134 but also to define how to interpret that law. ${ }^{135}$

134. Marbury v. Madison, 5 U.S. (1 Cranch) 137, 177 (1803).

135. The plenary power to decide rules of interpretation seems to draw its roots from the Marshall Court's suggestion that certain powers inhere to courts qua courts. In United States v. Hudson \& Goodwin, 11 U.S. (7 Cranch) 32 (1812), the Court recognized that "certain implied powers must necessarily result to our Courts of justice from the nature of their institution." Id. at 34. This implies that the power derives ultimately from Article III's vesting of the federal judicial power in the Supreme Court and the inferior federal courts. 